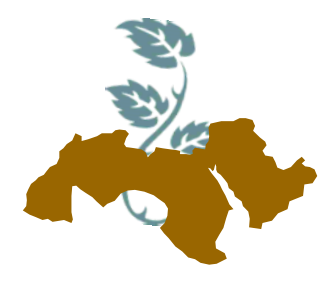

\title{
OPTIMIZING IRRIGATION WATER BY DETECTING ACTIVE ROOT DEPTH USING NUCLEAR TECHNIQUE
}

\author{
Gomaa' A.I.; Hegazi $^{2}$, M.M.; El-Bagoury ${ }^{2}$, Kh.F. and Youssef', Kh.M. \\ 1- Soil and Water Dept., Nuclear Research Center, Atomic Energy Authority, Egypt \\ 2- Agric. Eng. Dept., Fac. of Agric., Ain Shams Univ., Cairo, Egypt
}

Keywords: Active root depth, Neutron probe, chickpea, FWUE, CWUE.

\section{ABSTRACT}

The experiment was carried out at the farm of soils and water research department, atomic energy authority. Inshas (latitude $30^{\circ} 24^{\prime}$ longitude $31^{\circ} 35^{\prime}$ ) altitude is $20 \mathrm{~m}$ above the sea level, during $(2015 / 2016)$ growth season. The treatments of the water $\left(T_{1}, T_{2}, T_{3}\right)$, were applied, which was $(100 \%$, $80 \%$ and $60 \%$ ), respectively based an estimated amount of applied water to active root depth (ARD) which estimated according to the amount of water depleted from field capacity through ARD.

Actual evapotranspiration, yield, crop water use efficiency and active root depth were measured and estimated. The obtained results showed that the highest value of chickpea grain yield was $1218.09 \mathrm{~kg} / \mathrm{ha}$ under $\mathrm{T}_{2}$ treatment compared with $1170.37 \mathrm{~kg} / \mathrm{ha}$ and $919.99 \mathrm{~kg} / \mathrm{ha}$ for $\left(\mathrm{T}_{1}, \mathrm{~T}_{3}\right)$ respectively. Also the highest value of crop water use efficiency was btained by $T_{2}$ which was 0.28 $\mathrm{kg} / \mathrm{m}^{3}$ flowed by $T_{3}$ then $T_{1}$ which were 0.26 and $0.22 \mathrm{~kg} \mathrm{~m}^{-3}$ respectively. Difference between the $T_{1}, T_{2}$ and $T_{3}$ was found with grain yield and actual evapotranspiration between three treatments. Active root depth reached a maximum value was 71 $\mathrm{cm}$, which approximates the actual value.

\section{INTRODUCTION}

Irrigation scheduling is the decision of farmers regarding the "when" the irrigation and how much water is required to be applied in each irrigation event. (Fue and Sanga, 2015).

Shock et al (2007) reported that irrigation scheduling involves determining the correct timing and depth of water necessary to maintain root zone moisture within the optimal range for crop growth. Irrigation uniformity is related to how evenly water is distributed over the field area. Active root depth is the depth of soil at which plant extracts most of its absorbed water. El-Gendy et al (2000) defined ARD as the soil depth, which separates the soil profile into two parts the upper one at which effect of evapotranspiration is dominant while, the second one represents the effect of gravity (deep percolation). Active root depth increase during the growing season as the crop develops. It begins at zero at planting and increases to its maximum depth with time, which occurs approximately at the midseason for most crop. This result can be estimated from the in situ measurements where hydraulic gradient equal zero $(\mathrm{dH} / \mathrm{dZ}$ $=0)$ at $(H, Z)$ function. So this depth is very important to identify the separate line in soil profile between the lower parts, at which water is lost by deep percolation and the upper parts at which water is lost through evaporation process and plant uptake.

The active root zone has the potential to return water to the atmosphere via evapotranspiration, and the depth of this zone affects the extent of the exchange between soil-moisture and water vapor (Guswa, 2008).

The aims of this study are, optimizing of irrigation water by drip irrigated chickpea for best irrigation management.

\section{MATERIALS AND METHODS}

\subsection{Materials}

\subsubsection{The experimental site}

A complete randomize field experiment was conducted at the farm of Nuclear Research Center, Atomic Energy Authority, Inshas, during (2015 /2016) growing season. 


\subsubsection{Physical and chemical properties.}

- The following properties were measured and determined according to Jacobs et al (1971).

- Total porosity was calculating using the following equation

$\phi=[1-\rho b / \rho s]$ $\phi:$ Total porosity, $\mathrm{cm}^{3}$.

$\rho b$ : soil bulk density, $\mathrm{g} / \mathrm{cm}^{3}$.

$\rho s$ : particle density, $\mathrm{g} / \mathrm{cm}^{3}$ ( assuming 2.65)

-Residual moisture content $\left(\theta_{\mathrm{r}}\right)$ was determined as soil moisture content at $\mathrm{dh} / \mathrm{dZ} \approx$ zero at soil moisture retention curve (SMRC).

- Soil bulk density was determined according to Blake and Hartge (1986).

- Pore size distribution was estimated according to deLeenheer and de Boodt (1965)

Table 1. Some physical properties of the investigated soil

\begin{tabular}{|c|c|c|c|c|c|c|c|c|c|}
\hline \multirow{2}{*}{$\begin{array}{l}\text { Soil depth } \\
\quad(\mathrm{cm})\end{array}$} & \multicolumn{3}{|c|}{$\begin{array}{c}\text { Particle size } \\
\text { distribution \% }\end{array}$} & \multirow{2}{*}{$\begin{array}{c}\text { Texture } \\
\text { Class }\end{array}$} & \multirow{2}{*}{$\begin{array}{c}\text { Bulk density } \\
\text { g/cm }\end{array}$} & \multirow{2}{*}{$\begin{array}{c}\text { FC } \\
\%\end{array}$} & \multirow{2}{*}{$\begin{array}{c}\text { Total } \\
\text { porosity } \\
\mathrm{cm}^{3}\end{array}$} & \multirow{2}{*}{$\begin{array}{c}\theta \text { at } 0.1 \\
\text { bar }\end{array}$} & \multirow{2}{*}{$\begin{array}{c}\theta \text { at } 15 \\
\text { bar }\end{array}$} \\
\hline & Sand & Silt & Clay & & & & & & \\
\hline 15 & 96.7 & 1.1 & 2.2 & Sand & 1.55 & 9.5 & 0.42 & 8.5 & 1.90 \\
\hline 30 & 98.5 & 0.7 & 0.8 & Sand & 1.78 & 8.4 & 0.33 & 8.5 & 1.90 \\
\hline 50 & 98.5 & 0.8 & 0.7 & Sand & 1.77 & 8.4 & 0.33 & 8.5 & 1.79 \\
\hline 70 & 97.9 & 0.7 & 1.4 & Sand & 1.77 & 8.4 & 0.33 & 8.5 & 1.78 \\
\hline 90 & 97.7 & 0.7 & 1.6 & Sand & 1.73 & 8.4 & 0.35 & 8.4 & 1.78 \\
\hline
\end{tabular}

Table 2. Some chemical properties of investigated soil

\begin{tabular}{|c|c|c|c|c|c|c|c|c|c|c|c|}
\hline \multirow[t]{2}{*}{ Soil depth, $(\mathrm{cm})$} & \multirow[t]{2}{*}{$\begin{array}{c}E C \\
(\mathrm{dS} / \mathrm{m})\end{array}$} & \multirow[t]{2}{*}{ *pH } & \multicolumn{4}{|c|}{$\begin{array}{c}\text { Soluble cations } \\
(\mathrm{m} \mathrm{eq} / \mathrm{L})\end{array}$} & \multicolumn{4}{|c|}{$\begin{array}{c}\text { Soluble anions } \\
\text { (m eq/L) }\end{array}$} & \multirow[t]{2}{*}{ SAR } \\
\hline & & & $\mathrm{K}^{+}$ & $\mathbf{M g}^{++}$ & $\mathrm{Ca}^{++}$ & $\mathrm{Na}^{+}$ & $\mathrm{CO}_{3}{ }^{--}$ & $\mathrm{HCO}_{3}^{-}$ & $\mathrm{Cl}^{-}$ & $\mathrm{SO}_{4}^{--}$ & \\
\hline 15 & 3.78 & 7.2 & 1.31 & 20.87 & 7 & 8.65 & - & 0.32 & 10 & 24.6 & 1.67 \\
\hline 30 & 0.62 & 7.2 & 0.56 & 1.93 & 1.47 & 2.19 & - & 0.35 & 4.75 & 1.05 & 1.68 \\
\hline 50 & 0.38 & 7.4 & 0.31 & 0.93 & 0.81 & 1.71 & - & 0.35 & 3.3 & 0.11 & 1.83 \\
\hline 70 & 0.29 & 7.3 & 0.5 & 0.63 & 0.32 & 1.49 & - & 0.35 & 2.4 & 0.19 & 3.24 \\
\hline 90 & 0.4 & 7.1 & 0.63 & 0.85 & 0.24 & 2.26 & - & 0.38 & 3.4 & 0.2 & 2.81 \\
\hline
\end{tabular}

${ }^{*} \mathrm{pH}(1: 2.5$ Soil / Water suspension)

\subsubsection{Irrigation system}

Drip irrigation system was used to irrigate the chick pea plant. The system consists of:

- Control head, consist of sandy and screen media filters, pressure gauges and control valves

- Pipes Polyethylene (PE) tube $50 \mathrm{~mm}$ diameter for main and sub main lines, while the lateral tubes was $16 \mathrm{~mm}$ diameter of PE built in drip line $4 \mathrm{~L} \mathrm{hr}^{-1} / 30 \mathrm{~cm}$ at an operating pressure of 1 bar to serve crop rows.

\subsubsection{Cultivated Crop}

Chickpea seeds (Cicer arietinum.) Giza 531 variety was selected as the test plant, the amount of seeds required was $98.8 \mathrm{~kg} / \mathrm{ha}$. The seeds planted at spacing of $30 \mathrm{~cm}$ between plants and $50 \mathrm{~cm}$ between rows.

\subsubsection{Fertilization}

Chemical fertilizers were injected into irrigation water along the growing season according to plant stages growth needs through progressing stages according to Ministry of Agriculture. 
All the experimental plots had the same characteristics and the same crop management's practices soil preparations, Fertilizers NPK were used at recommended rate.... etc.

\subsection{Measurements and calculations}

\subsubsection{Active Root Depth (ARD)}

ARD will be estimate by detecting hydraulic gradient within the soil profile to obtain the evapotranspiration drip and drainage effects at $(\mathrm{H} / \mathrm{dZ}=$ $0)$.

van Genuchten (1980) presented his model to represent soil moisture retention curve ( SMRC) as the flowing equation

$\theta_{h}=\theta_{r}+\left(\theta_{s}-\theta_{r}\right)\left[1+(\alpha h)^{n} J^{m}\right.$

Tensiometric method was used to determined Soil matric suction according to (kholood, 2004).

\section{Where:}

$\mathrm{h}$ : the soil matric potential, mbar

$h_{b}$ : the air entry suction, mbar

$\theta_{r}$ : residual soil moisture, $\mathrm{cm}^{3} \mathrm{~cm}^{-3}$

$\theta_{s}$ : saturation point, which equals total porosity $\mathrm{m}$ and $\mathrm{n}$, constants for fitting soil moisture retention curve, and
Z: the soil depth, mbar

$\mathrm{H}$ : the hydraulic potential, $\mathrm{m}$ bar.

By rewriting this model to predict the soil matric suction ( $h, m b a r)$ as the flowing equation

$h=-(1 / \alpha)[(\mathrm{Se})-1 / m-1] 1 / n$

Where:

$$
\mathrm{Se}=\left(\left(\boldsymbol{\theta}-\boldsymbol{\theta}_{\mathrm{r}}\right) /\left(\boldsymbol{\theta}_{\mathrm{s}}-\boldsymbol{\theta}_{\mathrm{r}}\right)\right)
$$

Total hydraulic potential $(H)$ in unsaturated state is the summation of both matric and gravitational potentials as the flowing equation

$H=-h-Z$

Where:

$\mathrm{h}$ : the soil matric potential at $\mathrm{Z}$ soil depth, the negative sign before $Z$ because the reference level was taken at the surface soil. The total hydraulic potential can be obtained at $Z$ soil depth using substitution $\mathrm{h}$ from Eq.2 in Eq.3 as shown in Eq.4:

$H=-h_{b}\left[\left(\left(\theta-\theta_{r}\right) /\left(\theta_{s}-\theta_{r}\right)\right)-1 / m-1\right] 1 / n-Z$

After obtaining values of the total hydraulic potential along the soil profile, it can be obtained on the relationship between $\mathrm{H}$ and $\mathrm{Z}$ shown in Fig. (1) to determined ARD

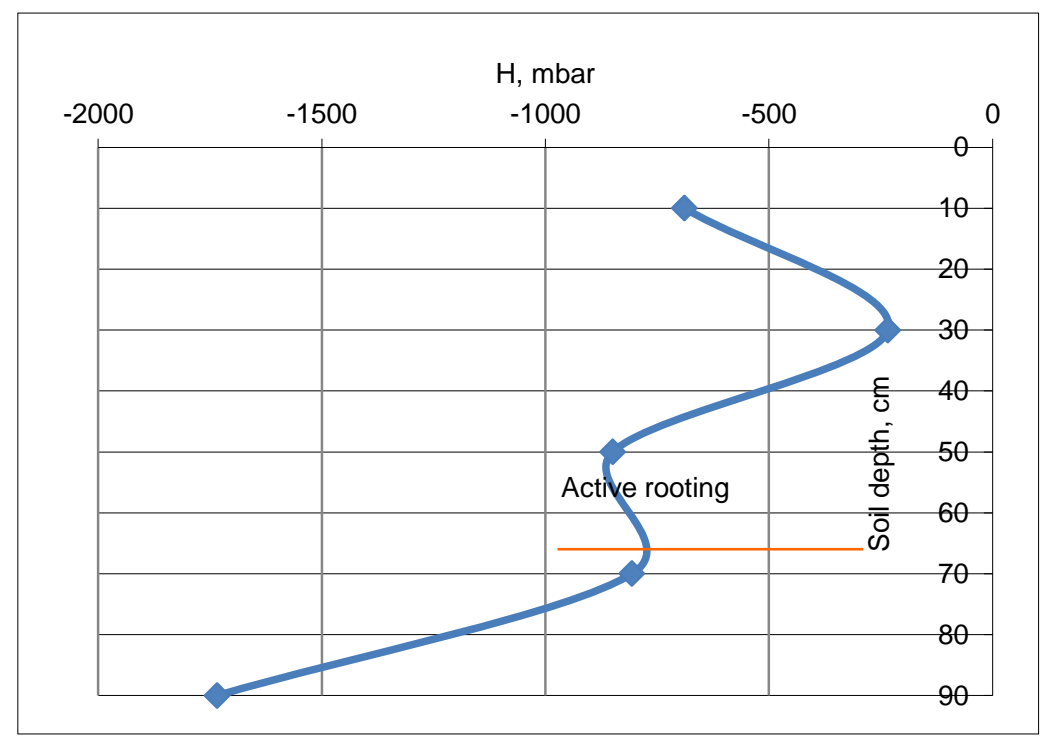

Fig. 1. Direction of soil water movement after and before irrigation for the experimental data 
The values of water were estimated by the following equation:

$$
\left.W R=\left(\theta_{f . c}-\theta_{\text {b.n. } i}\right) \times(D / 100) \times A \times 1 / E_{i}\right)
$$

Where:

WR : Irrigation water requirement, $\mathrm{m}^{3}$ $\theta_{\text {f.c }}:$ the soil water content at field capacity, $\%$ $\theta_{\text {b.n.i }}:$ the soil water content before irrigation, $\%$ A: the experimental plot area, $\mathrm{m}^{2}$, and $\mathrm{D}$ : the soil depth, $\mathrm{cm}$.
$1 / E_{i}$ : the inverse of irrigation system efficiency. Israelsen and Hansen. (1962)

\subsubsection{Actual evapotranspiration $\left(E T_{a}\right)$}

Actual evapotranspiration $\left(\mathrm{ET}_{\mathrm{a}}\right)$ was estimated in situ by calculation soil moisture depletion in root zone by detection soil moisture content from $30 \mathrm{~cm}$ up to $90 \mathrm{~cm}$ de Boodt et al (1967).

Deep percolation was estimated by the difference between the applied water and $\mathrm{ET}_{\mathrm{a}}$.

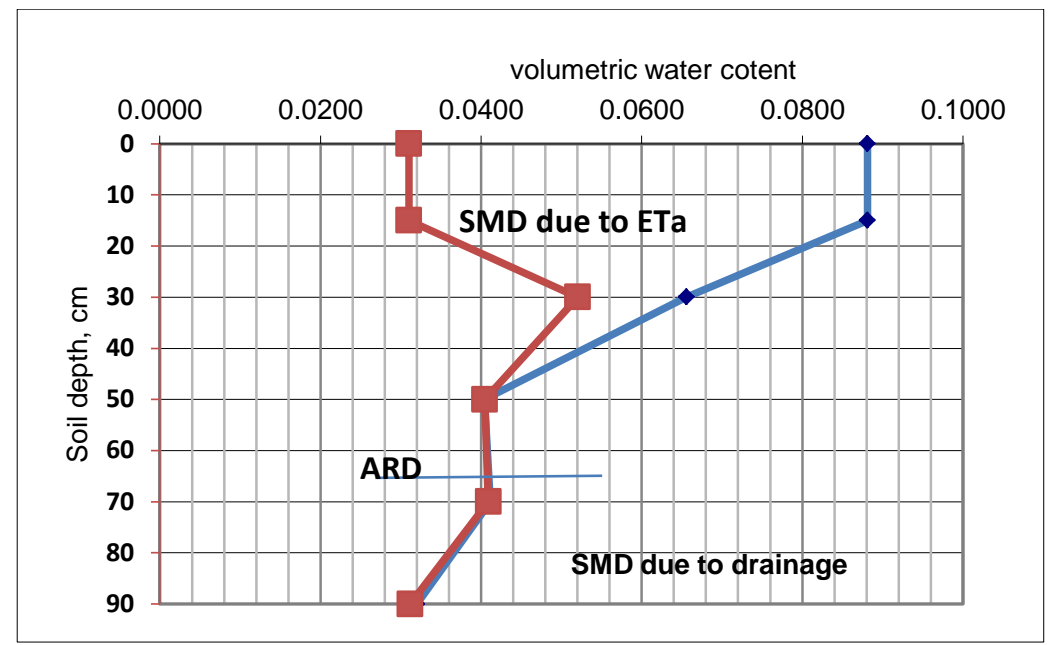

Fig. 2. Soil moisture distribution within the soil profile

The soil moisture depletion at certain was estimated by the following equation:

$S M D=0.5^{\star}\left(\theta_{a r}-\theta_{b}\right)+\left(\theta_{a}-\theta_{b}\right)^{\star} Z$

\section{Where:}

SMD: Soil water depletion, $\mathrm{mm}$

$\theta_{\mathrm{a}}$ : the soil water content after irrigation.

$\theta_{\mathrm{b}}$ : the soil water content before the next irrigation.

$\mathrm{Z}$ : soil depth, $\mathrm{mm}$

\subsubsection{Moisture measurement}

Soil moisture content was measured gravimetrically in the upper layer $(15 \mathrm{~cm})$ and by the neutron probe CPN, $50 \mathrm{mCi}$. (503 DR hydro probe), Americium-241 Beryllium $m$ source according to IAEA (2008) for deeper depths (30, 50, 70 and 90cm) were determined for soil under study. Soil moisture content was measured before irrigation and 2 hours after irrigation.

\subsection{4. crop water use efficiency and Filed water use efficiency}

CWUE = Total grain yield $(\mathrm{Kg} / \mathrm{ha}) /$ actual evapotranspiration $\left(\mathrm{m}^{3} / \mathrm{ha}\right) \mathrm{Kg} / \mathrm{m}^{3}$

Field water use efficiency (FWUE) was calculated after (Michael, 1978)

$F W U E=Y / W R$

Where:

Y: Seed yield ( $\mathrm{kg} / \mathrm{ha})$

WR: The total amount of water applied in the field (m3/ha).

\subsection{Experimental design}

Completely randomized design with three treatment of water $\left(\mathrm{T}_{1}, \mathrm{~T}_{2}, \mathrm{~T}_{3}\right)$, were applied, which was $(100 \%, 80 \%$ and $60 \%)$, respectively and with three replicated was used in this experiment. The experimental area was $296.4 \mathrm{~m}^{2}$. shown in Fig. (3). 


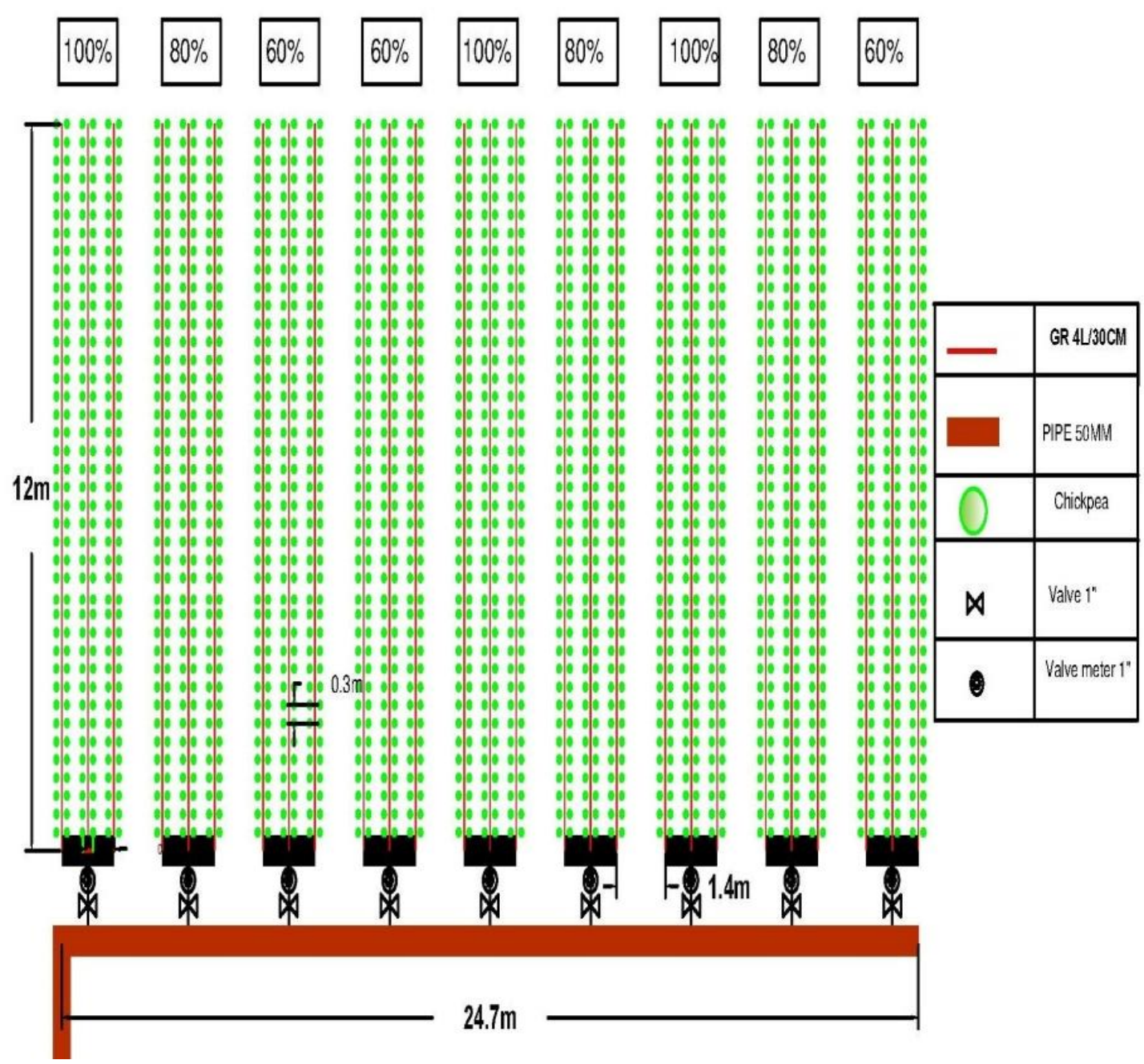

Fig. 3. Experimental Design

\section{RESULT AND DISCUSSION}

3.1. Calibration for neutron probe and active root depth

\subsubsection{Neutron calibration curves}

Fig. (4) and Table (3) illustrate the linear relationship between water content and count ration $(\mathrm{CR})$ for Neutron probe at depth $(30,50,70$ and 90$) \mathrm{cm}$ soil depth. The result shown in Table (3) and this result agree with Sallam and
El-Gendy, (1999) which they founded that $R$ average from 0.94 to 0.97 This means that the results are expressed and the relation between water content and count ration is positive.

\subsubsection{Active root depth}

Table (4) show Calibration of active root depth where founded that development stages showed the highest value was $68 \mathrm{~cm}$ compared actual root depth which recorded $60 \mathrm{~cm}$ even reached $71 \mathrm{~cm}$ at the end season compared with the actual root depth value of which recorded $75 \mathrm{~cm}$. 


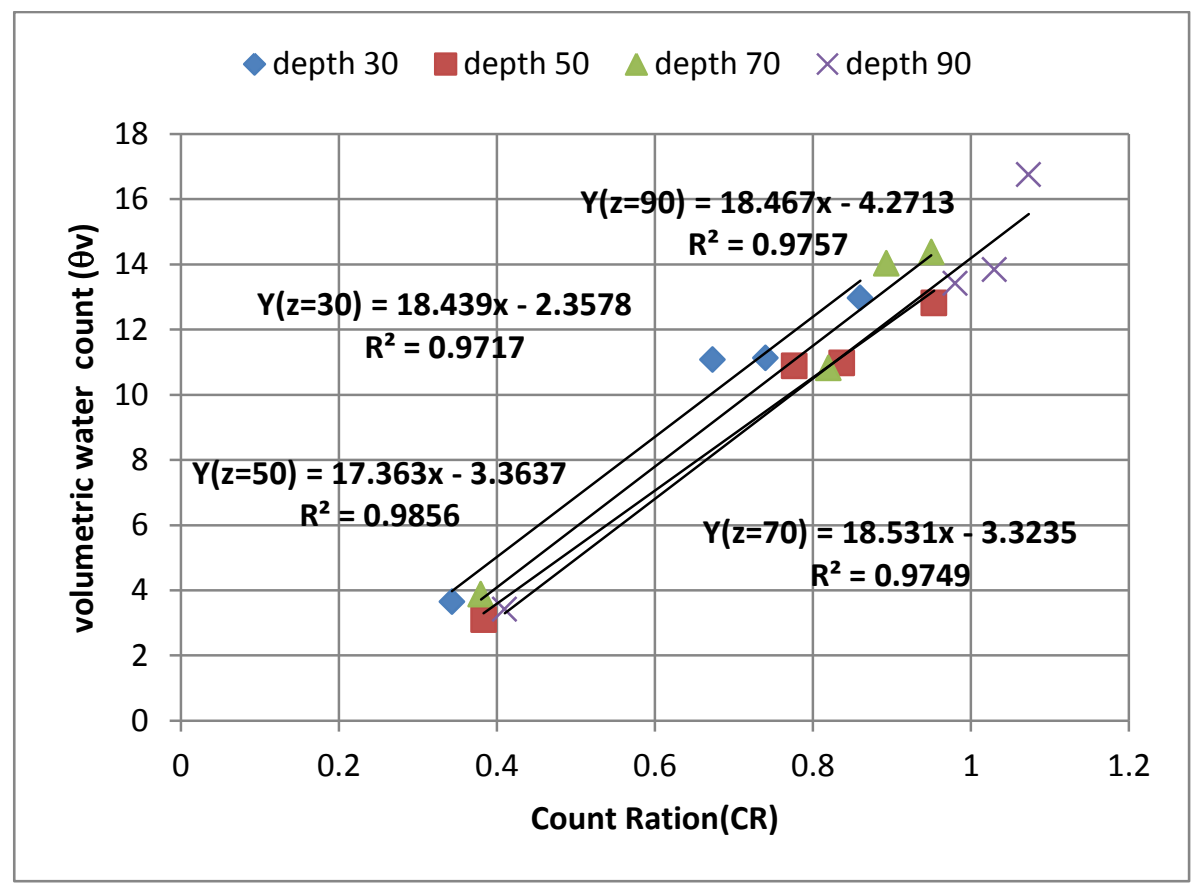

Fig. 4. Neutron calibration curves for four depth

Table 3. Regression equations of neutron calibration curves at different soil depths of the treatments under study

\begin{tabular}{|c|c|c|}
\hline Depths & Regression equation & $\begin{array}{c}\text { Coefficient of } \\
\text { determination } \\
\mathbf{( R}^{\mathbf{2}} \mathbf{)}\end{array}$ \\
\hline 30 & $\theta=18.439$ C.R-2.3578 & 0.9717 \\
50 & $\theta=17.363$ C.R -3.3637 & 0.9856 \\
70 & $\theta=18.531$ C.R -3.3235 & 0.9749 \\
90 & $\theta=18.467$ C.R -4.2713 & 0.9757 \\
\hline
\end{tabular}

Table 4. Calibration lengths of chickpea for each stages

\begin{tabular}{|c|c|c|}
\hline \multirow{2}{*}{ Stage } & \multicolumn{2}{|c|}{ Active root depth (cm) } \\
\cline { 2 - 3 } & Measured & actual \\
\hline \multirow{2}{*}{ Initial } & 12 & 15 \\
Mid & 68 & 60 \\
End & 71 & 75 \\
\hline
\end{tabular}

\subsection{Applied water by active root depth}

The mean seasonal $\mathrm{ET}_{\mathrm{a}}$ were $534.60,435.42$ and $347.32 \mathrm{~mm}$, respectively for $\left(T_{1}, T_{2}, T_{3}\right)$. The highest seasonal $E T_{a}$ was recorded by treatment $T_{1}$, whereas the lowest seasonal $E T_{a}$ recorded under $\mathrm{T}_{3}$. The relation between actual evapotranspiration $\left(\mathrm{ET}_{\mathrm{a}}\right)$ and climatic factors is important to evaluate the accurate treatment for estimating plant water requirements. Values of $\mathrm{ET}_{\mathrm{a}}$ indicated that the total amount of water actually used by plant in increase with increasing the applied water.

Daily evapotranspiration from the date of planting to harvesting indicates that evapotranspiration started with lower values in initial stage, increased gradually in development and mid-season stages and decreased toward harvest due to physiological maturity of crop. There was a significant difference in total amount $\mathrm{ET}_{\mathrm{a}}$ between the three irrigation treatments. 
Don Scott (2000), added that the relation between the force of attraction of water by soil surfaces and water content is an inverse relationship; that's means the first layers of water is held with great forces of attraction, the magnitude of the forces of attraction for water decrease as the distance from the partial surface increase. Therefore, addition more amount of irrigation as in $T_{1}$ water give the opportunity to irrigation water to evaporate from soil surface more than $\mathrm{T}_{2}$, also evaporation process from $T_{2}$ was more than $T_{3}$.

Table 5. Applied water (mm)

\begin{tabular}{|c|c|c|c|c|}
\hline & Date & \multicolumn{3}{|c|}{ applied water } \\
\hline & (2015-2016) & $\mathrm{T}_{1}$ & $\mathrm{~T}_{2}$ & $T_{3}$ \\
\hline \multirow{2}{*}{ NOV. } & *14-21 & 62.94 & 62.94 & 62.94 \\
\hline & $22-30$ & 18.16 & 14.53 & 10.90 \\
\hline \multirow{4}{*}{ Dec. } & $1-7$ & 7.78 & 6.22 & 4.67 \\
\hline & 8--15 & 7.22 & 5.78 & 4.33 \\
\hline & $16-23$ & 8.32 & 6.66 & 4.99 \\
\hline & 24-31 & 13.99 & 11.19 & 8.39 \\
\hline \multirow{4}{*}{ Jan } & $1-7$ & 4.97 & 3.98 & 2.98 \\
\hline & $8--15$ & 13.02 & 10.42 & 7.81 \\
\hline & $16-22$ & 26.96 & 23.56 & 13.79 \\
\hline & $23-30$ & \multicolumn{3}{|c|}{ Rain fall = $3.3 \mathrm{~mm}$} \\
\hline \multirow{4}{*}{ Feb. } & $1-7$ & 31.39 & 19.18 & 18.29 \\
\hline & $8--15$ & 82.48 & 59.13 & 46.24 \\
\hline & $16-22$ & 53.15 & 34.73 & 30.50 \\
\hline & $23-30$ & 53.70 & 35.40 & 30.28 \\
\hline \multirow{4}{*}{ Mar. } & $1-7$ & 54.72 & 35.81 & 31.00 \\
\hline & 8--15 & 45.50 & 28.83 & 26.43 \\
\hline & $16-22$ & 54.08 & 34.59 & 30.65 \\
\hline & $23-30$ & 49.49 & 35.34 & 28.99 \\
\hline \multirow{2}{*}{ Apr. } & $1-7$ & 56.59 & 35.88 & 30.47 \\
\hline & $8--15$ & 51.19 & 34.05 & 29.85 \\
\hline
\end{tabular}

${ }^{*}$ Agriculture day

\subsection{Grain yield and crop water use efficiency (CWUE)}

\subsubsection{Grain Yield}

Chick pea grain yield obtained under the three irrigation treatments is shown in Fig. (4). It was $1170.37,1218.09$ and $919.99 \mathrm{~kg} \mathrm{ha}^{-1}$ for $\mathrm{T}_{1}, \mathrm{~T}_{2}$ and $T_{3}$, respectively shown in Table (6). The grain yield obtained with $\mathrm{T}_{2}$ was recorded $3.96 \%$ higher than $\mathrm{T}_{1}$. In addition, with $\mathrm{T}_{1}$ treatment resulted there was a significant reduction in crop yield.

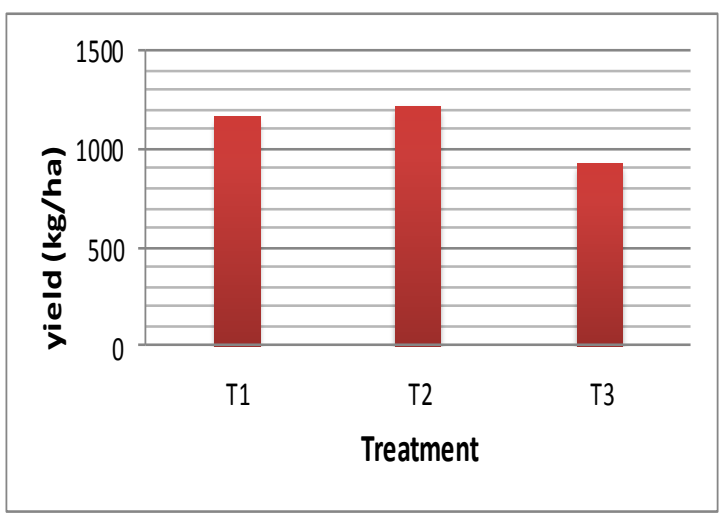

Fig. 4. Grain yield production for three treatments

\subsubsection{Crop water use efficiency (CWUE)}

Crop Water use efficiency (CWUE) was $(0.22$, 0.28 and $0.26 \mathrm{Kg} / \mathrm{m}^{3}$ ) and filed Water use efficiency (FWUE) was $\left(0.17,0.24\right.$ and $\left.0.22 \mathrm{~kg} / \mathrm{m}^{3}\right)$ for three treatments $\left(T_{1}, T_{2}\right.$ and $\left.T_{3}\right)$ respectively (presented in Table 6). $T_{2}$ recorded highest values of CWUE and FWUE compared with treatment $\mathrm{T}_{1}$ and $T_{3}$. The high values was obtained by improving both crop yield and water saving.

Table 6. Applied water (mm), grain yield (kg/ha), crop water use efficiency and filed water use efficiency $\left(\mathrm{kg} / \mathrm{m}^{3}\right)$

\begin{tabular}{|c|c|c|c|}
\hline & $\mathbf{T}_{\mathbf{1}}$ & $\mathbf{T}_{\mathbf{2}}$ & $\mathbf{T}_{\mathbf{3}}$ \\
\hline Water applied (mm) & 698.94 & 501.48 & 426.78 \\
Grain yiled $(\mathrm{kg} / \mathrm{ha})$ & 1170.37 & 1218.09 & 919.99 \\
CWUE $\left(\mathrm{Kg} / \mathrm{m}^{3}\right)$ & 0.22 & 0.28 & 0.26 \\
FWUE $\left(\mathrm{Kg} / \mathbf{m}^{3}\right)$ & 0.17 & 0.24 & 0.22 \\
\hline
\end{tabular}

\section{Conclusions}

Three water treatments (100\%, $80 \%$, and $60 \%)$ of ARD were established. The results showed that $80 \%\left(T_{2}\right)$ treatment recorded the highest results in chickpea yield (1218.09 kg/ha), crop water use efficiency $\left(0.28 \mathrm{~kg} / \mathrm{m}^{3}\right)$ and water saving $(27.83 \%)$ in comparison with $\left(T_{1}\right)$, which gave the greatest value from Deep percolation $(201.75 \mathrm{~mm})$ that cause to increase applied water and decrease both of yield and crop water use efficiency. 


\section{REFERENCE}

Blake, G.R. and Hartge, K.H. 1986. Bulk Density, in A. Klute, ed., Methods of Soil Analysis. Part I. Physical and Mineralogical Methods: Agronomy Monograph No. $92^{\text {nd }}$ ed., pp. 363-375.

De-Boodt, M.R., Hartman, M.R. and Messter, P., 1967. Isotope and Radiation techniques in soil physics and irrigation studies. IAEA proceedings 12-16 June SM-94/25, pp. 147-160.

DeLeenheer, I., and De Boodt, M. 1965. Soil physics. International training course for postgraduate. Soil Scientists, Ghent. (C.F: Kholood, 2011).

Don Scott, H. 2000. Soil physics: Agricultural and environmental applications. lowa State University Publication.

El-Gendy, R.W., Abd El-Moniem, M. and Massoud, M.A. 2000. In Situ Measurements for Calculating Evapotranspiration Values Using Neutron Moisture Meter. Seventh Conference of Nuclear Sciences \& Applications 6-10 February 2000, Cairo, Egypt, pp. 1320-1328.

Fue, K.G. and Sanga, C. 2015. Remote Scheduling System for Drip Irrigation System Using Geographic Information System. J. of Geographic Information System, 7, 551-563.

Guswa, A.J. 2008. The influence of climate on root depth: A carbon cost-benefit analysis. Water Resources Research, 44, 1-11.

IAEA, 2008. Field estimation of soil water content: practical guide to methods, Instrumentation and Sensor Technology. Training course series 30 Vienna, Australia, pp. 39-43.
Israelsen, O.W. and Hansen, V.E. 1962. Irrigation principles and practices $3 \mathrm{rd}$ ed., John Willey and Sons., New York, USA. pp. 308-319.

Jacobs. H.S., Reed, R.M., Thien, S.J., and Withee, L.V. 1971. Soils laboratory exercise source book. Am. Soc. of Agron. Mandison, Wisconsin, USA. (C.F: Kholood, 2011).

Kholood, M.M. 2004. Prediction of soil moisture retention curve and unsaturated hydraulic conductivity for some soils using neutron scattering method. M.Sc. Thesis, Ain Shams University, Cairo, Egypt, pp. 22-25.

Kholood, M.M. 2011. Water Management In Sandy Soil Using Neutron Scattering Method. Ph.D. Thesis, Ain Shams Univ., Cairo, Egypt, 41 p.

Michael, A.M. 1978. Irrigation: Theory and practice. $1^{\text {st }}$. Vikas publishing house PVT Ltd. New Delhi. India, pp. 547-548.

Miyazak, T. 2006. Water flow in soils. $2^{\text {nd }}$ ed .CRC Press/Taylor\& Francis, Boca Raton, London, New York, USA, pp. 9-10.

Sallam, M.F.A. and El-Gendy, R.W. 1999. Detecting active root depth using soil water movement direction by nuclear technique. Egypt. J. Soil . Sci., 39(1), 27-43.

Shock, C.C., Pereira, A.B. and Eldredge, E.P. 2007. Irrigation best management practices for potato. American J. of Potato Research. 84, 29-37.

van Genuchten, M.T.1980. A closed form equation for predicting the hydraulic conductivity of unsaturated. Soil Sci. Soc. Am. J., 44, 513522. 